\title{
Pengembangan dan Pembinaan Karier Pegawai
}

\author{
Oleh : Supardi
}

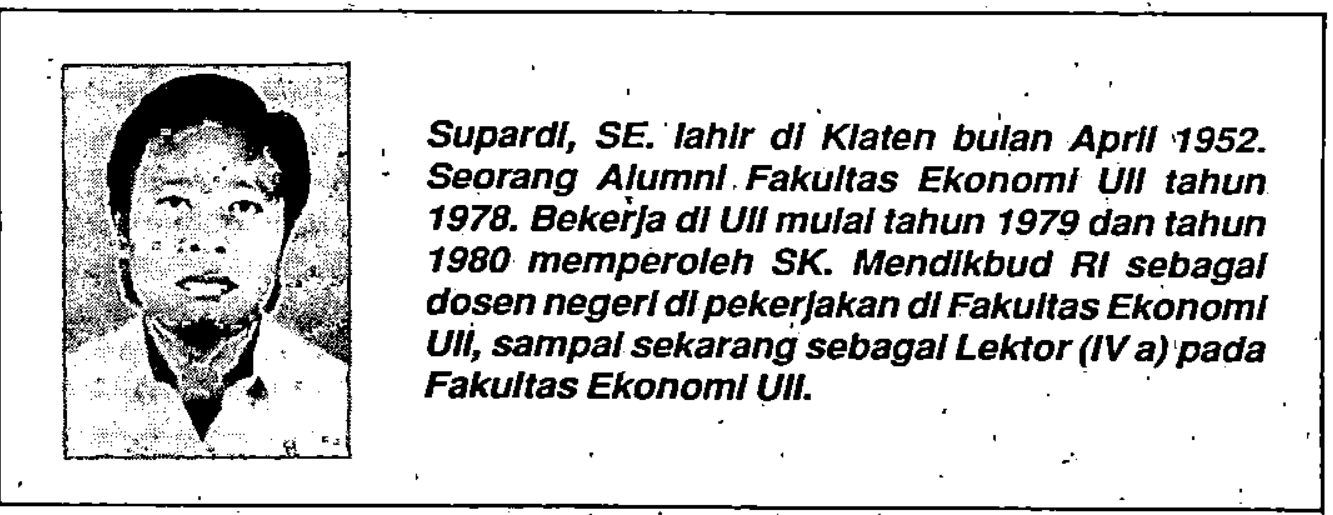

Pendahuluan

Semua organisasi baik organisasi yang berbentuk badan usaha (bisnis), organisasi yayasan, organisasi pemerintah, maupun organisasi sosial lainnya, akan memiliki tujuan-tujuan yarig menjadi motivasi untuk beraktivitas. Tujuan organisasi secara umum adalah pengelolaan sumber daya (faktor-faktor produksi) secara "sehat" yaitu tercapainya efektivitas dan efisiensi setiap aktivitas yang dilakukan.

Sumber daya yang ada pada setiap organisasi akan meliputi sumber daya fisik (prasarana dan sarana), sumber daya uang (dana), metode kerja dan sumber daya manusia. Sumber daya manusia merupakan sumber daya utama dan mempunyai peranan yang "menentukan" dalam upaya mencapai tujuan organisasi yaitu efektivitas dan efisiensi yang tinggi. Oleh karena itu dalam organisasi, manajemen sumber daya manusia harus memperoleh tempat dan penanganan yang terencana dan terus menerus.

Namun demikian masalah yang dihadapi setiap organisasi adalah bagaimana membuat sumber daya dapat dimanaj (=dikelola) secara efektif dan efisien, terutama sumber daya manusianya (pegawai).

Bahan (material) dan sumber daya fisik, begitu mudah dibeli dan dimiliki. Namun setelah dibeli tidak atau kurang usaha untuk merawat dan memeliharanya secara baik dan kontinyu. Mesin dan peralatan yang modem ("canggih") dengan 
mudah dapat dibeli, namun sering dijumpai dalam suatu organisasi, para pegawainya tidak dapat mem-pergunakan dengan baik, sehingga kurang memberikan sumbangan optimal dalam mencapai efektivitas dan efisiensi kerja. Ini semua karena belum tersiapkan pegawai yang memadai untuk menangani secara baik dalam penggunaan, perawatan maupun pemeliharaan perangkat keras atau sumber daya fisik yang dimiliki suatu organisasi.

Sebuah organisasi dengan mudah mendapatkan sumber daya uang (dana), baik diperoleh dari donatur, pinjaman maupun dari pemiliknya. Namun pada saat dituntut untuk mengembalikan sum-ber dana tersebut banyak organisasi yang sulit. dapat memenuhi secara "tepat". Hal ini kembali kepada tidak atau kurangnya ketersediaan pegawai yang terdidik dan terlatih untuk mengelola dana suatu organisasi. .

Dari kasus-kasus tersebut dan mungkin banyak lagi kasus yang lainnya yang 'menyangkut pengelolaan sumber daya organisasi. Kesemuanya ini kembali pada manajemen pegawai pada organisasi yang bersangkutan. Diperiukan kesiapan, kesigapan, kemampuan dan kemauan para pegawai untuk bekerja dan ber-kembang dengan baik guna mening-katkan metode kerja dalam mencapai efektivitas dan efisiensi sumber daya organisasi.

\section{Efektivitas dan Efisiensi Organisasi.}

Efektivitas dan efisiensi seperti dua kata yang nampak tidak dapat dipisahkan dalam pengelolaan organisasi: Dua kata ini menupakan suatu variabel untuk mengukur suatu prestasi kerja seseorang maupun organisasi.
- Efektivitas sering diartikan kemampuan seseorang atau organi-sasi untuk memilih dan menetapkan kegiatan-kegiatan dan sumber daya-sumber daya secara tepat untuk mencapai tujuan yang telah ditetapkan. Dengan perkataan lain seseorang maupun organisasi dapat dikatakan efektif, manakala seseorang dan organisasi tersebut dapat memilih dan menetapkan pekerjaan dan metode-metode kerja yang tepat padá sasaran mencapai tujuan yang telah ditetapkan.

Efisiensi diartikan adalah kemampuan seseorang atau organisasi untak melakukan pekerjaan dengan benar, yaitu hasil suatu pekerjaan dapat dikatakan benar, manakala hasil pekerjaan (out-put) dibanding-kan dengan pengorbanan (input) yang diperiukan untuk menghasilkan out-put tersebut. Seseorang atau organisasi dapat dikatakan bekerja secara efisien, manakala out-put yang dihasilkan lebih tinggi dibanding dengan in-put yang dịkorbankannya.

Dari uraian tersebut kiranya jelas bahwa padá setiap diri seseorang maupun suatu organisasi dituntut untuk mencapai tingkat efektivitas dan efisiensi yang tinggi dalam méngelola suatu organisasi. Bukan saja pegawai pada organisasi perusahaan, organisasi pemerintahan maupun organisasi yang berbentuk koperasi dan berbentuk yayasan sekalipun.

\section{Pengembangan. Pegawai.}

Pengembangan pegawai adalah proses dan usaha meningkatkan kemampuan dan kemauan pegawai, agar dalam melaksanakan tugas pekerjaan yang sedang àtạu yang akan ditugaskan kepada pegawai tersebut 'dapat lebih efektif dan 
lebih efisien. Dengan perkataan lain bahwa tujuan pengembangan pegawai adalah :

- Meningkatkan kemampuan bekerja, baik pengetahuan, ketrampilan maupun wawasan pegawai.

- Meningkatkan kemauan bekerja, yang berarti meningkatkan kepemimpinan, motivasi dan kreativitas maupun inovasinya.

- Meningkatkan kemampuan menghadapi kemajuan metode kerja dan teknologi dalam bekerja, berarti mempersiapkan tenaga kerja masa depan.

-' Usaha menunjang program pembinaan karier (man power planning)

Untuk dapat mencapai tujuan tersebut, maka harus ada usaha-usaha secara nyata yang terencana dan terus menerus pengembangan pegawai yang ada pada suatu organisasi. Cara atau metode yang kiranya dapat dipergunakan dalam pengembangan pegawai diantaranya adalah

- Belajar mandiri, pegawai secara individual ditugaskan atau dengan kesadaran sendiri berupaya meningkatkan kemampuan dan kemauan kerja dengan belajar baik melalui membaca maupun observasi pekerjaan.

- Mengikuti kursus dan penataran baik yang dišelenggarakan institusinya (kantor) maupun yang diselenggarakan lembaga-lembaga. pendidikan.

- Mengikuti perputaran pekerjaan (jabatan) dengan istilah lain tour of duty. Penugasan dalam bentuk perpindahan pekerjaan akan dapat mematangkan kemampuan pegawai kearah generalis dengan wawasan yang lebih luas.

- Mengikuti pertemuan-pertemuan ilmiah, pengajian, melihat pameran industri maupun teknologi dan lain sebagainya.

\section{Pembinaan Karier Pegawai.}

Pembinaan karier ini dipergunakan sebagai istilah dalam peluang seorang pegawai untuk lebih maju. Istilah ini sebenamya termasuk dalam pengertian pengembangan pegawai, namun istilah pembinaan karier ini lebih spesifik sebagai usaha untuk menciptakan kemungkinan seorang pegawai. dapat meniti atau menapak jabatan (kedudukan) yang lebih tinggi. Dengan demikian yang dimaksud dengan pembinaan karier adalah tugas setiap individu dan para pemimpin untuk menciptakan peluang/kesempatan agar mampu menduduki jenjang jabatan yang lebih tinggi.

Kepemimpinan suatu organisasi harus mampu meningkatkan ke-hidupan kerja séseorang dalam hubungannya dengan pekerjaan. Para pegawai tidak saja memerlukan upah/gaji yang tinggi maupun kondisi tempat kerja yang menye-nangkan, akan tetapi mereka juga perlu diberikan kesempatan dan kemampuan bagi para pegawai mendayagunakan potensi dan kemampuannya untuk menggeluti pekerjaan yang lebih baik dan diminatinya. Dengan demikian setiap manajemen atau pemimpin suatu organisasi mempunyai kewajibain mengembangkan dan mengintegrasi-kan karier individu para pegawai agar 
mendayagunakan potensinya untuk memajukan organisasinya.

Pembobotan pekerjaan menjadi sangat diperlukan agar manajer mampu - memilih orang yang tepat pada pekerjaan, sehingga penem-patan seorang pegawai pada jabatan yang lebih tinggi dapat dipilih yang benar-benar "mampu" atau memenuhi syarat jabat (prinsip the right man on the right place). Untuk itulah diperlukan analisis jabätan guna" memperoleh deskripsi jabatan mau-pur spesifikasinya (syarat-syarat orangnya).

Penilaian prestasi kerja pegawai secara jujur / obyektif, akan dapat mewarnai program pembinaan karier seseorang. Ketidak tepatan memilih seorang pegawai untuk menduduki jabatan yang lebih tinggi atau lebih strategis akan mempunyai 2 kerugian utama, yaitu kerugian pekerjaan yáng tidak dapat diselesaikan yang bersangkutan dengan secara efektif dan efịsien. Kerugian yang kedua akan menimbulkan salah pengertian pada pegawai yang lainnya, yang mungkin lebih "pas" untuk jabatan tersebut. Pegawai yang lain akan "frustasi"', karena mestinya bukan orang tersebut tetapi telah dipilih atasannya dan sehingga muncul istilah "like and dislike" dalam pembinaan karier. Dampak lebih lanjut motivasi kerja dan loyalitas dapat "terganggu".

Ketepatán pembinaan karier seorang pegawai dapat ditentukan pula oleh adanya ketepatan dalam proses perekrutan pegawai pada awalnya. Perekrutan yang tidak akura, cermat memperoleh pegawai akan berdampak panjang dengan sulitnya pegawai tersebut dikembangkan. Apalagi harus mempersiapkan pegawai untuk dapat menduduki jábatan yang lebih tinggi dan strategis. Oleh karena itu, maka setiap organisasi dituntut dapat melakukan perekrutan pegawai yang memadai dengan kebutuhan pegawai pada masa depan, bukan saja melakukan perekrutan pegawai untuk mengatasi persoalan jangka pendek. Organisasi harus mampu mempersiapkan pegawai masa depan yang memadai dengan istilah dalam manajemen personalia disebut dengan "man power planning".

Kiranya yang tidak akalah penting dalam hal pembinaan karier ini adalah seorang pemimpin harus mampu mempelajari siklus atau tahapan karier seseorang. Gary Dessler memberikan pengelompakan tahapan perjalanan karier seseorang sebagai berikut :

Tahapan pertama seseorang adalah pertumbuhan, yaitu seseorang yang berumur sampai dengan 14 tahun. Pada tahapan ini seseorang sedang mengembangkan suatu citra pribadi dengan mengidentifikasikan dirinya dan berinteraksi dengan orang lain seperti keluarga, guru dan kawan-kawan.

Tahapan kedua adalah eksplorasi (umur 15-24 tahun), seseorang berusaha menggali berbagai altematif keahlian secara serius, dengan upaya membandingbandingkan antara altematif yang didapat dengan hal-hal yang telah dipelajarinya baik mengenai tata nilai, motif (minat dan bakat), ambisi-ambisi maupun pengambilan keputusan pilihan.

Tahapan berikutnya adalah pemantapan (25-44 tahun). Pada tahap inilah yang sering disebut dengan inti kehidupan kerja pada setiap diri seseorang. Oleh karena terjadi pilihàn pemantapan, maka pada tahapan ini terbagi menjadi sub tahapan percobaan (25-30 tahun) dengan ciri pada tahap ini seseorang menentukan apakah bidang pekerjaan yagn telah dipilih cocok atau tidak, bila tidak cocok akán meninggalkan atau melakukan perubahan/ 
penye-suaian. Sub tahapan kedua tahap stabilisasi (30-40 tahun), dengan pertanda dimana tujuan pekerjaan ditetapkan dan - orang yang bersangkutan merencanakan karier lebih eksplisit untuk menentukan urutan promosi (peningkatan jabatan struktural), perubahan pekerjaan dan atau aktivitas pendidikan yang diperlukan untuk mencapai tujuan semula. Dan sub tahapan terakhir.dari tahap pemantapan ini adalah seseorang pada usia akhir dari angka 30 an dan memasuki 40 an yang disebut sebagai masa krisis karier pertengahan. Seseorang melakukan penilaian kembali kemajuankemajuan yang tercapai dalam hubungannya dengan ambisi-àmbisi dan tujuan dirinya semula. Oleh karena mereka melakukan penilaian kembali, maka akan terjadi pengambilan keputusan ulang yaitu terus dengan kariernya atau harus mengorbankan kariernya untuk kembali pada tujuan dan ambisi-ambisi semula yang telah digariskan.

Tahap berikutnya adalah pemeliharaan (45-65 tahun), pada tahap ini seseorang telah menciptakan suatu tempat dalam dunia kerja dan semua upaya untuk mengamankan tempat tersebut. Dan tahap terakhir adalah masa kemunduran yaitu seseorang telah memasuki masa pensiun' dari kerja, mereka harus mẹninggalkan dunia kerja untuk memasuki dunia istirahat.

\section{Siapa yang bertanggung jawab ?}

Setelah mengetahui arti dan berbagai aktivitas dalam rangka pengembangan -maupun pembinaan karier pegawai termasuk beberapa hal yang harus memperoleh perhatian pada uraian sebelumnya, maka pertanyaannya sekarang adalah siapa yang bertanggungjawab dalam program pengembangan dan pembinaan karier para pegawai itu?

Pengembangan sumberdaya manusia dalam suatu organisasi akan terletak pada individu yang ada pada organisasi tersebut apakah mereka sebagai bawahan ataupun sebagai pemimpin. Oleh karena itu tanggungjawab. utama dalam pengembangan dan pembinaan pegawai adalah individu. pegawai itu sendiri dan setiap diri pimpinan organisasi.

Individu pegawai sangat menentukan ada tidaknya serta menentukan pula berhasil tidak program pengembangan dan pembinaân pegawai di organisasi tersebut. Manakala dalam suatu, organisasi terdapat orang-orang statis dan tidak memiliki sasaran kerja yang jelas akan mendorong organisasi untuk tidak menyelengga-rakan program, dan kalau toh dilakukan program kiranya tidak-akan memperoleh respon dan partisipasi yang optimal dari para pegawai. Oleh karena itu banyak organisasi yang maju program pengembangan dan pembinaan karier pegawainya, manakala para pegawai memiliki motivasi besar untuk lebih maju dan berkembang, berpikir dinamis dan jauh kedepan. Dengan prinsip hari esok yang lebih maju dan hari esuk yang lebih baik dan cerah. Pada organisasi yang memiliki manusia yang kreatif dan' dinamislah yang akan memiliki program pengem-bangan dan pembinaan pegawai yang optimal.

Disamping itu bagaimanapun peranan pemimpin organisasi sangat menentukan pula dalam program pengembangan dan pembinaan pegawainya. Pemimpin yang statis dan kurang suka jikalau bawahannya lebih mampu, pintar dalam pekerjaan, lebih maju dan lain sebagainya akan sangat 
menghambat adanya dan keberhasilan pengembangan maupun pembinaan pegawai. Ingin majunya para pegawai tanpa diberikan kesempatan oleh para memimpin, sama saja akan tercipta rasa tidak puas dalam kerja yang akhirnya performance organisasi tidak akan nampak baik dan maju. Oleh kàrena itu peranan pemimpin untuk memajukan para bawahan sangat menentukan, paling tidak kemampuan untuk memotivasi, memberikan kesempatan untuk maju dan penjenjangan yang lebih obyektif, syukursyukur mampu menciptakan berbagai program pendidikan, latihan serta program pengembangan dan pembinaan karier yang lainnya dengan memberikan kesempatan dan pembiayaan yang memadai. Insyaalloh individu pegawai akan lebih mampu kerja dan maju yang dampak akhimya juga nilai organisasi akan meningkat.

Sedang pihak yang lainya yaitu organisasi-organisasi pegawai (serikat pekerja) yang juga memiliki andil untuk mendorong keberhasilan program pengembangan dan pembinaan pegawai pada induk organisasinya.

Pemerintahan dengan berbagai peraturan perundangan yạng berlaku dapat mendorong dan mengatur terselenggaranya program pengem-bangan dan pembinaan karier pegawai pada suatu organisasi baik itu organisasi bisnis maupun organisasi non bisnis.

\section{Penutup}

Dari uraian tersebut kiranya jelas bagi setiap organišasi baik itu organisasi bisnis maupun non bisnis bahwa pemecahan masalah yang berkaitan dengan pemanfaatan sumberdaya manusia agar mencapai efektivitas dan efisiensi organisasi terletak kepada kemampuan para pegawainya (sumberdaya manusianya). Oleh karena itu pegawai merupakan asset organisasi yang sangat menentukan keberhasilan organisasi.

Dengan demikian setiap organisasi dituntut untuk selalu mengembangkan dan membina kariet para pegawainya agar mampu memberikan nilai tambah bagi organisasinya. Dengan pengembang-an dan pembinaan karier dengan berbagai bentuk dan faktor yang diperhatikan maka akan mampu menciptakan manusiamanusia maju dimasa depan atau dapat menciptakan "man power planing" yang optimal.

Keberhasilan program pengembangan dan pembinaan pegawai akan terletak pada diri individu pegawai yang bersangkutan dan setiap pemimpin organịsasi, dengan perannya masingmasing.

\section{DAFTAR PUSTAKA}

Abdul Rachman Shaleh dan Siddik Muhtadi, Takwa sebagai Dasar Pembinaan Tertib Administrasi, Gunung Agung, Jakarta, 1982.

Gary Dessler (Terj.). Manajemen Personalia, Penerbit Erlangga, Jakarta, 1984.

Heidjractiman Ranupandojo dan Suad Hus nan, Manajemen Personalia, , edi si ketiga, BPFE, Yogyakarta, 1986.

Kartini Kartono (Penyunting), Menyiapkan dan Memandu Karier, CV. Rajawali, 1985.

Mochtar Effendi, Manajemen suatu Pendekatan Berdasarkan Ajaran Islam, Penerbit Bhratara Karya Aksara, Jakarta, 1986.

Sudibyo Triatmodjo, Hukum Kepegawai an, Ghalia Indonesia, Jakarta, 1983 Sondang P Siagian, Teori dan Praktek Kepemimpinan, Bina Aksara, Jakarta, 1988.

T. Hani Handoko, Manajemen, edisi Il, PBFE-YK dan LMP2M AMP YKPN, Yogyakarta, 1986. 